\title{
マクロモノマー法を用いた高分子微粒子の設計 Polymer Particle Design Using Macromonomer Method
}

\author{
川口正 剛 ${ }^{*}$ \\ Seigou KAWAGUCHI
}

\section{1.はじめに}

マクロモノマーは重合性（反応性）の官能基を有する ポリマーあるいはオリゴマーの総称であり, 文字通り高 分子とモノマーの両方の性質を有する。低分子コモノマー との共重合は少なくても枝成分既知のグラフト高分子を, 単独重合は高密度の櫛形高分子を与える ${ }^{122}$ 。近年の高 分子合成技術の進歩に伴い, 様々なマクロモノマーが合 成できるようになり，目的に応じた，テーラーメイドな グラフト高分子が設計可能な時代に入っている。

高分子微粒子合成におけるマクロモノマーの利用の利 点は, (1) マクロモノマーの高分子性に基つくく高い立体 安定化作用, (2) マクロモノマーの重合性（反応性）に 基づくクリーンな（分散剤および乳化剩が重合中消費さ れ微粒子表面にグラフト高分子として取り込まれる）微 粒子合成, (3) 機能性マクロモノマーに基づく微粒子表 面の高機能化，などが上げられる゙)。

本稿では, 分散重合による機能性微粒子合成の最近の 進歩を述べた後, マクロモノマーを重合性の分散剂とし て用いた分散重合や微粒子径制御に関する一般原理と課 題について総説する。

\section{2. 分散重合}

分散重合は，重合前には完全に“均一な溶液”から立 体安定化高分子の存在下で重合を行うことによって高分 子微粒子が形成される沈殿重合の 1 つとして定義される (図 1)。一般に分散重合によって得られる微粒子の粒子 径は $200 \mathrm{~nm}$ から $10 \mu \mathrm{m}$ の範囲にあり, 乳化重合之縣濁

\footnotetext{
*山形大学工学部機能高分子工学科 米沢市城南 4-3-16 于992-8510 Department of Polymer Science and Engineering, Faculty of Engineering, Yamagata University, 4-3-16, Jonan, Yonezawa 992-8510, Japan
}

重合の中間の粒子径を与える。特にミクロンサイズの䍩 分散微粒子を与える点で興味が持たれている。

この重合で用いられる連続相媒体の特徴は, モノマー や開始剤および分散安定化高分子（マクロモノマー）に 対しては良溶媒であること, 生成する高分子に対しては 非溶媒であること，したがって重合中形成するグラフト （プロック）高分子に対しては選択溶媒であることがあ げられる。これまで, 溶解度パラメーターが小さな炭化 水素系と大きなアルコール系が主として研究されてきた。 事実, 分散重合の最初の例は炭化水素媒体中, 適当な分 散安定化高分子の存在下で（メ夕）アクリル系極性モ） マーの重合によるあのであった4)。このようにして合成 された微粒子は, 水系乳化重合粒子との対比から Nonaqueous Dispersion (NAD) 粒子と呼ばれ, 特に楯料分 野で大きな関心がもたれた。その後,この重合法は Almog ら ${ }^{5)}$ によってアルコール采の極性媒体を連続相 として用いる重合系に拡張され, 研究者の関心が寄せら れることになった。分散重合は過去 20 年間に非常に多 くの研究と進展がなされており, 現在では多様な機能性 高分子微粒子が様々な媒体中で設計できるようになって きた ${ }^{6 \sim 9)}$ 。以下には新規な機能性微粒子の合成に関する 最近の進歩について紹介する。

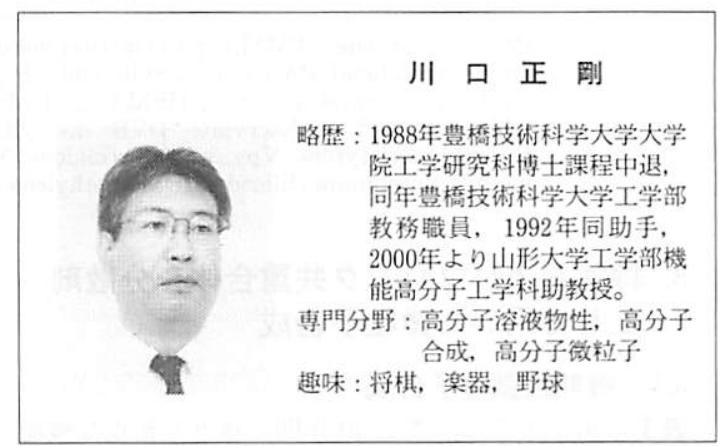




\section{重合前}

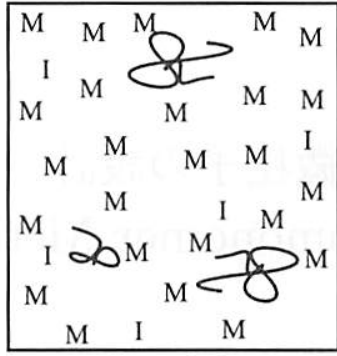

均一溶液

$\left[\begin{array}{l}\mathrm{M}: \text { モノマー I: 開始剤 } \\ \sim \text { : マクロモノマー }\end{array}\right]$
重合後

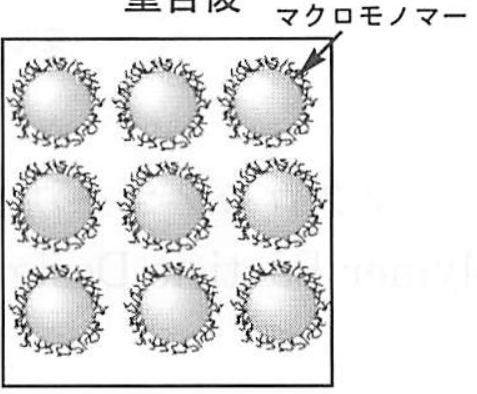

立体安定化微粒子

サイズ: $(0.2-15 \mu \mathrm{m})$

図 1 分散重合前後の溶液の模式図

表 1 分散重合法によって合成された機能性微粒子の合成例

\begin{tabular}{|c|c|c|c|}
\hline 分散剂 & モノマー & 連続相 & 文献 \\
\hline PS, PMMA 褋等体 & HEMA & 2-プタノール/トルエン & 10 \\
\hline Cellulose acetate butyrate & HEMA & アルコール/トルエン & 11 \\
\hline $\mathrm{PS}-b-\mathrm{PB}$ & $4 \mathrm{VP}$ & $\mathrm{DMF} /$ トルエン & 12 \\
\hline PVP & GMA & メタノール/水 or DMF & 13 \\
\hline PVP & GMA/DVB & エタノール & 14 \\
\hline PVP & ST/GMA & エタノール/水 & 15 \\
\hline Cellulose acetate & GMA & 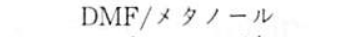 & 16 \\
\hline PVME & AAm & $t$-プタノール/水 & 17 \\
\hline None & AAm & $t$-プタノール/水 & 18 \\
\hline PVP & CMS & エタノール/DMSO & 19 \\
\hline PAA & CMS & 2 -メトキシエタノール $/ \mathrm{MeOH}$ & 20 \\
\hline $\mathrm{PS}-b-\mathrm{P}(\mathrm{P}-a l t-\mathrm{E})$ & VPy & シクロヘキサン & 21 \\
\hline PVP & $\mathrm{ST} / \mathrm{NVC}$ & エ夕ノール & 22 \\
\hline $\begin{array}{l}\mathrm{PVA}-c o-\mathrm{PVAc} \\
\text { ハイブリッド微粒子 }\end{array}$ & ST & メタノール & 23 \\
\hline Poly (amic acid) & $\mathrm{ST} / 4 \mathrm{VBAC}$ & エタノール/水 & 24 \\
\hline PVP & ST/polyimide prepolymer & $i$ ープロパノール & 25 \\
\hline PVP & $\mathrm{GMA} / \mathrm{Fe}_{2} \mathrm{O}_{3}$ & アルコール/水 & 26 \\
\hline Cellulose acetate butyrate & $\mathrm{HEMA} / \mathrm{GMA} / \mathrm{Fe}_{2} \mathrm{O}_{3}$ & アルコール/トルェン & 27 \\
\hline PVP & $\mathrm{HEMA} / \mathrm{EDMA} / \mathrm{Fe}_{2} \mathrm{O}_{3}$ & アルコール/トルエン & 28 \\
\hline PVP & $\mathrm{ST} / \mathrm{SiO}_{2}$ & エ夕ノール/水 & 29 \\
\hline \multicolumn{4}{|l|}{ 架橋微粒子 } \\
\hline PVP & DVB & アセトニトリル or エタノール & 30 \\
\hline None & DVB & アセトニトリル & 31 \\
\hline None & DVB/CMS & アセトニトリル & 32 \\
\hline $\mathrm{PS}-b-\mathrm{P}(\mathrm{P}-a l t-\mathrm{E})$ & Oxazoline methacrylate & ヘプタン & 33 \\
\hline PVP-Aerosol-OT & ST/urethane acrylate & エ夕ノール & 34 \\
\hline PVP & MMA/EGDMA & エ夕ノール/永 & 35 \\
\hline
\end{tabular}

PS: poly (styrene), PMMA: poly (methyl methacrylate), PB: poly (butadiene), PVP: poly (Nvinylpyrrolidone), PAA: poly (acrylic acid),.P: propyrene, E: ethylene, PVA: poly (vinyl alcohol), PVAc: poly (vinyl acetate), HEMA: 2-hydrozyethyl methacrylate, 4VP: 4-vinylpyridine, GMA: glycidyl methacrylate, DVB: divinylbenzene, ST: styrene, AAm: acrylamide, CMS: chloromethylstyrene, Vpy: vinylpyrrolidone, NVC: N-vinyl carbazole, 4VBAC: vinylbenzyltrimethyl ammonium chloride, EDMA: ethylene dimethacrylate, MMA: methyl methacrylate.

\section{3. 線状およびブロック共重合体を分散剂 として用いた微粒子合成}

\section{1 機能性微粒子合成 ${ }^{10 \sim 35)}$}

表 1 に示すようにここ 10 年間に様々な新規な機能
性微粒子が分散重合法によって合成できるようになった。 一般的なスチレンやアクリレートモノマーの他に，2ヒドロキシェチルメタクリレート (HEMA)，4-ビ二 ルピリジン (4VP)，グリシジルメタクリレート (GMA), アクリルアミド $(\mathrm{AAm})$, さらにはクロロメチルスチ 
レン (CMS), ピニルピロリドン (Vpy), N-ピニルカ ルパソール (NVC) などの機能性微粒子が適切な分散 剂存在下, 適切な媒体中（混合溶媒）で合成されている。 特に, アルコールや炭化水素媒体以外の溶媒としてトル. エン, DMF, DMSO 等の混合溶媒が用いられており， 連続相媒体の選択がきわめて重要であることを示してい る。

また，表面がポリイミドで覆われた微粒子， $\mathrm{Fe}_{2} \mathrm{O}_{3}$ や $\mathrm{SiO}_{2}$ を内包したハイブリット微粒子す分散重合によっ て合成できるようになってきた。また，ポリジビニルべ ンゼンからなる高架橋微粒子もアセトニトリル中, 分散 剂の有り無しに関係なく合成されている。

3.2 リビング分散重合による微粒子の合成 ${ }^{36 \sim 50}$ リビング重合を用いた微粒子合成は, 分子量の制御や リビング末端の機能化およびブロック共重合体微粒子の
合成が可能なため興味深い。表 2 にその研究例をまとめ た。スチレンやブタジェン等のリビングアニオン分散重 合が炭化水素媒体で行われ，分子量分布の狭い高分子か らなる微粒子が合成されている。特に近年その発展が著 しいリビングラジカル重合は（1) TEMPOなどの安定 ラジカル媒介, (2) 原子移動 (ATRP), (3) 可逆付加開裂 連鎖移動 (RAFT)) 機能性微粒子合成に非常に魅力的 な方法であり，今後の発展が望まれる。

\section{3 ビニルモノマー以外の微粒子合成 ${ }^{51 \sim 61)}$}

表 3 にはビニルモノマー以外のモノマーからなる分散 重合の例を示す。典型的な導電性高分子であるポリア二 リンやポリピロール微粒子がアルコールー水媒体中, 酸 化分散重合によって合成されている。また, 䣼素触媒重 合によるフェノール樹脂微粒子が分散重合によって合成 されている。

表 2 リピング分散重合による微粒子合成例

\begin{tabular}{|c|c|c|c|}
\hline 分散鼡 & モノマー & 連続相 & 文献 \\
\hline \multicolumn{4}{|l|}{ アニオン重合 } \\
\hline PS- $b$-poly (4-trimethylsilylstyrene) & ST & ヘキサン & 36 \\
\hline $\mathrm{PS}-b-\mathrm{PB}$ & ST & ヘキサン & 37,38 \\
\hline None & ST/butadiene & ペンタン & 39 \\
\hline PS-b-Poly (4-tert-butylstyrene) & ST & ヘキサン & 40,41 \\
\hline Poly (vinyl ethyl ether) & $\alpha$-methylstyrene & ヘプタン & 42 \\
\hline PS $-b$-PIB & $\mathrm{ST}$ & ヘキサン & 43 \\
\hline $\mathrm{PS}-b-\mathrm{P}(\mathrm{PP}-\mathrm{alt}-\mathrm{PE})$ & ST & 炭化水菜 & 44 \\
\hline $\mathrm{PS}-b-\mathrm{P}(\mathrm{PP}-\mathrm{alt}-\mathrm{PE})$ & MMA & ヘプタン & 45 \\
\hline $\begin{array}{l}\text { None } \\
\text { ラジカル重合 }\end{array}$ & $t$-butylstyrene/DVB & ヘプタン & 46 \\
\hline $\mathrm{PS}-b-\mathrm{P}(\mathrm{PP}-a l t-\mathrm{PE})$ & ST & デカン & 47 \\
\hline PVP & ST & アルコール/水 & 48 \\
\hline \multicolumn{4}{|l|}{ 開環重合 } \\
\hline $\begin{array}{l}\text { Poly (dodecyl methtacrylate })-g-\text { poly } \\
(\varepsilon \text {-caprolactone })\end{array}$ & $\begin{array}{l}\varepsilon \text {-caprolactone and } \\
\text { lactide }\end{array}$ & ヘプタン/ジオキサン & 49,50 \\
\hline
\end{tabular}

PIB: poly(isobutylene)，その他は表 1 參照。

表 3 ピニルモノマー以外の高分子微粒子

\begin{tabular}{|c|c|c|c|}
\hline 分散斉 & モノマー & 連続相 & 文献 \\
\hline \multicolumn{4}{|l|}{ 酸化重合 } \\
\hline PVP & Aniline & アルコール/水 & 51 \\
\hline PVME & Aniline & アルコール/水 & 52 \\
\hline PVA & Aniline & アルコール/水 & 53 \\
\hline Poly (styrenesulfonic acid) & Aniline & 水 & 54 \\
\hline Methylcellulose & Aniline & アルコール/水 & 55 \\
\hline Hydroxypropylcellulose & Aniline & 水 & 56 \\
\hline PVA & 3,5-Xylidine & 水 & 57 \\
\hline Ethylhydroxycellulose & Pyrrole & エ夕ノール/水 & 58 \\
\hline PVME & Pyrrole & エ夕ノール/水 & 59 \\
\hline \multicolumn{4}{|l|}{ 酳素重合 } \\
\hline PVME, PVA, PEG & Phenol & ジオキサン/リン酸緩衙液 & 60 \\
\hline PVME & $p$-Phenylphenol & ジオキサン/リン酸緩衙液 & 61 \\
\hline
\end{tabular}

PVME: poly (vinyl methyl ether), PEG: poly (ethylene glycol). 
表 4 マクロモノマー（反応性分散剂）を用いた分散重合の例

\begin{tabular}{|c|c|c|c|}
\hline 分散斉 & モノマー & 媒体 & 文献 \\
\hline PHSA 1 & MMA & 炭化水糍 & 4 \\
\hline PLMA 2 & MMA & 炭化水费 & 4 \\
\hline PE 3 & MMA & トデカン, PE & 62 \\
\hline PDMS 4 & ST & シリコンオイル & 63 \\
\hline POXZ 5 & MMA & メタノール/水 & 64 \\
\hline POXZ 5 & ST & エタノール/水 & 65 \\
\hline POXZ 5 & $\mathrm{CH}_{2}=\mathrm{CHNHCHO}$ & メタノール & 66 \\
\hline POXZ 6 & MMA & メタノール/水 & 67 \\
\hline $\mathrm{PEO} 7(\mathrm{~m}=1)$ & MMA, Styrene & エ夕ノール/水 & 68 \\
\hline PEO $8(\mathrm{~m}=3,5,7)$ & $\mathrm{ST}$ & エ夕ノール/水 & 69 \\
\hline PEO 9a & ST & エ夕ノール/水 & 70 \\
\hline PEO 9a, 11 & $\mathrm{~S}^{\prime} \mathrm{T}$ & エ夕ノール/水 & 71 \\
\hline $\operatorname{PEO} 7(\mathrm{~m}=1,4,7)$ & S'T, MMA, BMA & エ夕ノール/水 & $72,73,74$ \\
\hline PEO $9 b(m=11)$ & ST & エタノール/水 & 75 \\
\hline PEO 10 & ST, MMA & エ夕ノール/水 & 76 \\
\hline PEO $9 a, 9 b(m=6,10)$ & $\mathrm{ST}$ & エタノール/水 & 77 \\
\hline PEO 12 & $\mathrm{ST}$ & エ夕ノール/水 & 78 \\
\hline $\mathrm{PEO} 13$ & ST & エタノール/水 & 79 \\
\hline PVP 14 & ST, MMA & エタノール & 80 \\
\hline PVAcA 15 & $\mathrm{ST}$ & エ夕ノール & 81 \\
\hline PVA 16 & MMA & エタノール/水 & 82 \\
\hline P4VP 17 & ST & エタノール & 83 \\
\hline PNIPAM 18 & ST & エタノール & 84 \\
\hline PTBMA 19 & S'T & エ夕ノール & 85 \\
\hline PAA 20 & MMA & エタノール/水 & 86 \\
\hline PDMS 4 & MMA, ST & 二酸化炭素 & 87 \\
\hline PCL 21 & L, L-Lactide & ヘブタン/ジオキサン & 49,50 \\
\hline PMA 22 & MMA & エタノール/水 & 88 \\
\hline PDMAEMA 23 & $\mathrm{ST}$ & アルコール & 89 \\
\hline PEO 24 & ST & メタノール/水 & 90 \\
\hline Inimer 25 & ST, MMA & エタノール/水 & 91 \\
\hline Transurf 26 & $\mathrm{ST}$ & エタノール/水 & 92 \\
\hline
\end{tabular}

\section{4. マクロモノマーを用いた微粒子合成 ${ }^{4.62 ~ 92}$}

マクロモノマーを用いた分散重合の合成例を表 4 にま とめた。非極性媒体中ではポリ（12-ヒドロキシステアリ 酸) (PHSA)，ポリ（ラウリルメタクリレート）(PLMA), ポリエチレン (PE), ポリジメチルシロキサン等のマク ロモノマーが利用されている。アルコールー水系では, ポリ（オキサソリン（POXZ)，ポリ（エチレンオキシ ド) (PEO), ポリ（N-ビニルピロリドン）(PVP) 他, 多くのマクロモノマーが利用されている。また, マクロ モノマーのアソ開始剂 25 や末端チオール化 PEO 連鎖 移動剤 26 が用いられ，分散安定化や微粒子表面の高機 能化に利用されている。

\section{5. 微粒子系制御}

Paine $^{9)}$ は, アルコール中 PVP の存在下スチレンの 分散重合を連鎖移動によるグラフト共重合体の生成と, これによる立体安定化で定量的な説明を試みている。こ れを少量のマクロモノマー存在下での分散共重合に適用 すると, 図 2 のような 5 つの過程で重合が進行すると考
えられる。この過程の中で最も重要なところは，(4)の 立体安定化微粒子が形成される時点で，その時の粒子数 と重合率が求まれば最終的な粒子径が決定されるという ことになる。詳細は論文 ${ }^{73)}$ に譲るとするが, 微粒子半 径 R は最終的に（1）式で与えられる。

$R=\theta^{\frac{1}{3}}\left(\frac{3 W_{o}}{\rho N_{A}}\right)^{\frac{2}{3}}\left(\frac{M_{D} r_{1}}{W_{D o} S_{c r i t}}\right)^{\frac{1}{2}}\left(\frac{0.386 k_{2}}{4 \pi k_{p}}\right)^{\frac{1}{6}}\left(\frac{k_{t}}{2 k_{d} f[I]_{o}}\right)^{\frac{1}{12}}$

ここで, $\mathrm{W}_{\mathrm{o}}, \mathrm{W}_{\mathrm{D} o}, \mathrm{M}_{\mathrm{D}},[\mathrm{I}]_{0}$ は仕込みのモノマー, マク ロモノマー量, マクロモノマーの分子量および開始剤濃 度で, $k_{2}, k_{p}, k_{t}, k_{d}, f, r_{1}$ は, 同じ径の不安定微粒子 間の拡散律速凝集速度, 成長速度, 停止速度, 開始剂分 解速度定数および開始剂効率, モノマーを $M_{1}$ としたと

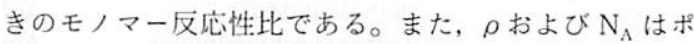
リマーの密度, アボガドロ数で, $\mathrm{S}_{\text {crit }}$ はマクロモノマー 1 分子が微粒子表面を覆うことができる面積であり，回 転半径 $\left\langle\mathrm{S}^{2}\right\rangle^{1 / 2}$ と次の関係式が成り立つ。

$$
S_{\text {crit }}=\frac{5}{3} \pi\left\langle S^{2}\right\rangle
$$

（1）式はマクロモノマーを用いた分散重合において, 
日本接着学会誌 Vol. 41 No. 11 (2005)

( 19 )【447】

構造式

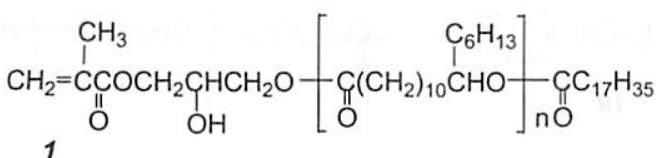<smiles>C=C(C)C(=O)OCC(O)COC(=O)CCC(C)(C)CC1(C)C2CCCC2(C)C1OCC</smiles>

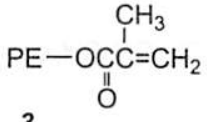

3

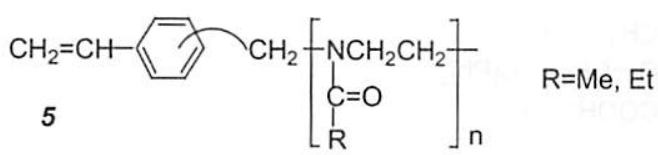

$\mathrm{CH}_{3} \mathrm{O}+\mathrm{CH}_{2} \mathrm{CH}_{2} \mathrm{O} \frac{\mathrm{n}}{\mathrm{n}}\left(\mathrm{CH}_{2}\right)_{\mathrm{m}} \longrightarrow-\mathrm{CH}=\mathrm{CH}_{2}$

$7 \quad(m=1,4,7)$

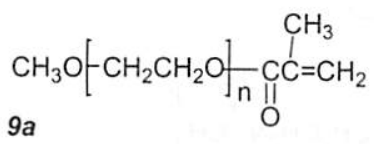

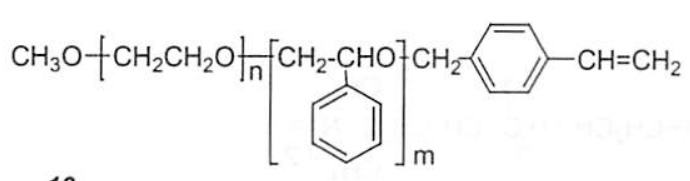

$10 \quad(m=2.6,4.1$, and 6.8$)$

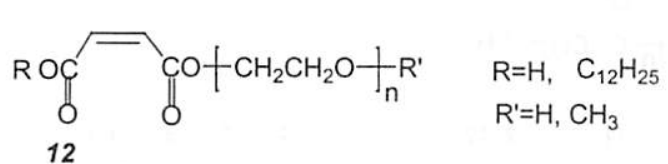
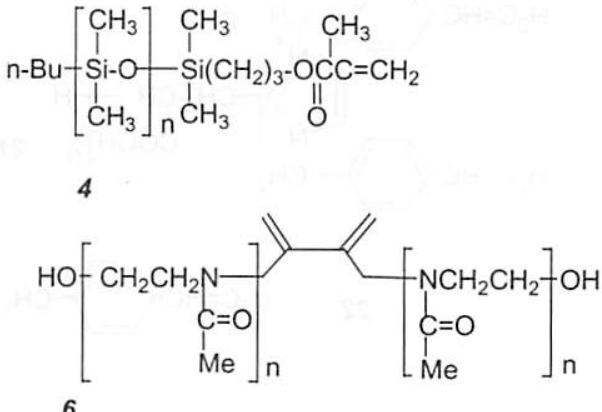

$\left.\mathrm{HO}+\mathrm{CH}_{2} \mathrm{CH}_{2} \mathrm{O}\right]_{\mathrm{n}}\left(\mathrm{CH}_{2}\right)_{\mathrm{m}} \longrightarrow-\mathrm{CH}=\mathrm{CH}_{2}$

$8(m=3,5,6)$<smiles>C=C(C)C(=O)OCCCCCCOC</smiles>

$9 b \quad(m=6,10,11)$<smiles>C=C(C)C(=O)OCCO</smiles>

11<smiles>C=C(C)c1ccc(C(C)(C)NC(=O)OCCCOC)cc1</smiles>

13<smiles>C=Cc1ccc(CCOC(=O)CCSCC(C)NC(C)=O)cc1</smiles><smiles>C=Cc1ccc(Cn2cc[n+](Cc3ccc(C=C)cc3)c2CC(O)C(C)C)cc1</smiles><smiles>C=Cc1ccc(CCOC(=O)CCSCCc2cc[n+](Br)cc2)cc1</smiles><smiles>C=Cc1cccc(CCOC(=O)CCSCCN2CCCC2=O)c1</smiles> 


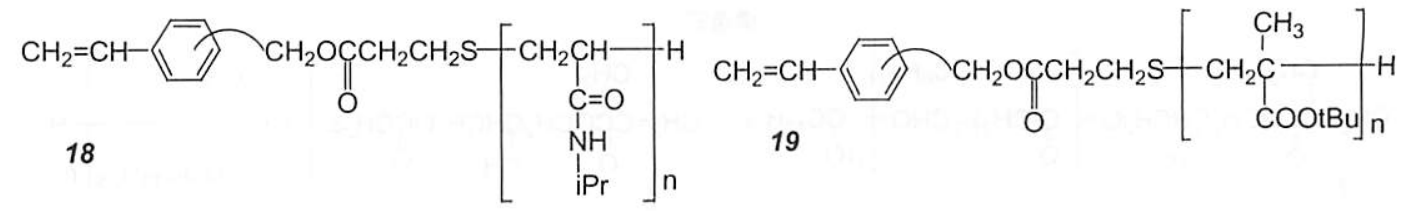

20

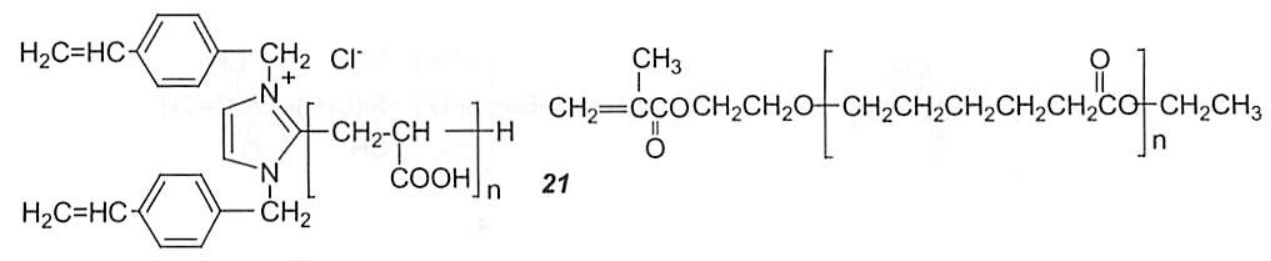

22
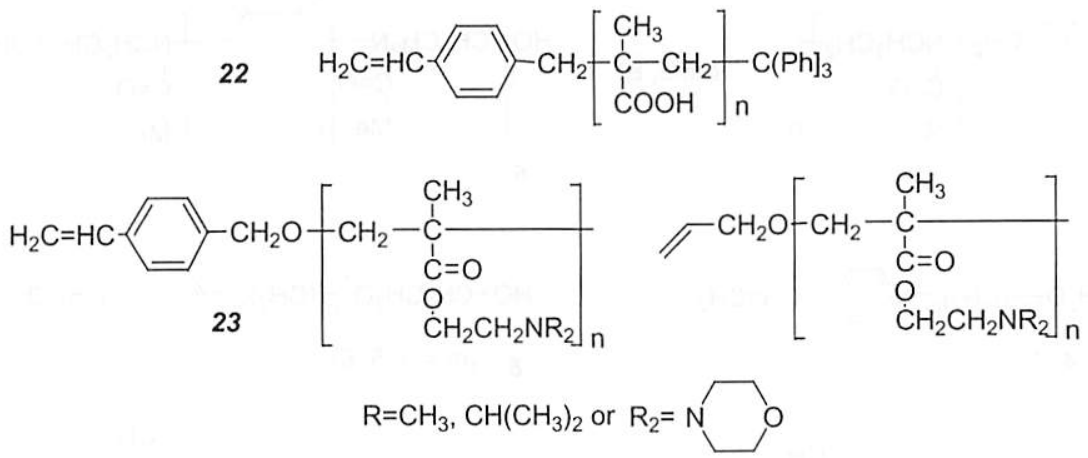

24

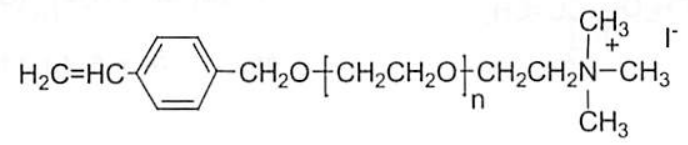

25

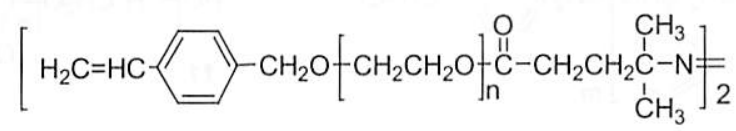

26

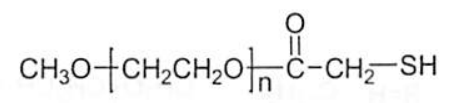

仕込み組成やマクロモノマーの分子量および構造, 溶媒 によって粒子径が設計・合成できることを示す基本式で ある。

表 $5 に$ に, 理論の妥当性を評価した研究例を示す。モ 八マー濃度依存性の指数 $\mathrm{a}$ は, 理論からの值 $(2 / 3)$ に 比べて一般的に高い。これは重合初期のモ/マーが溶媒 として振舞うために，ポリマー鎖に対する溶解性の向上 に起因していると考えられる。マクロモノマー濃度依存 性の指数 b はスチレン系の場合においては概称 $0.5 \pm 0.1$ の範囲になっており，理論との良い一致が観察された。 図 3 には, ポリエチレンオキシドマクロモノマー7 (m= $4, \mathrm{n}=45)$ を用いて, アルコールー水媒体中でのスチレ ンの分散共重合で得られる粒子径をマクロモノマー濃度
に対して両対数プロットしたものを示す。実線は $\theta=1$, $\rho=1.05 \mathrm{gcm}^{-3}, \mathrm{~N}_{\mathrm{A}}=6.02 \times 10^{12}, \mathrm{k}_{2}=10^{9} \mathrm{~L} \mathrm{~mol}^{-1} \mathrm{~s}^{-1}$, $\mathrm{k}_{\mathrm{p}}=350 \mathrm{~L} \mathrm{~mol}^{-1} \mathrm{~s}^{-1}, \mathrm{k}_{\mathrm{t}}=6.1 \times 10^{7} \mathrm{~L} \mathrm{~mol}^{-1} \mathrm{~s}^{-1}$, $\mathrm{k}_{\mathrm{d}}($ AIBN $)=3.2 \times 10^{-7} \mathrm{~s}^{-1}, \mathrm{f}=1, \mathrm{~S}_{\text {crit }}=10 \mathrm{~nm}^{2}, \mathrm{r}_{1}=1$ とした場合，(1) 式からの計算曲線である。実験值との 一致は極めて良好で，この重合が図 2 で示されるような 機構で進行していることを強く支持する。なお， $\mathrm{S}_{\text {crit }}=$ $10 \mathrm{~nm}^{2}$ の值は, PEO のアルコール中の回転半径を考元 ると極めて妥当な数値である。

一方, 極性モノマーである MMA の分散重合では, メ夕ノールー水 (8:2, 7:3) の場合, $\mathrm{b}=-1.2$ と異常に 高いマクロモノマー濃度依存性が観察された（表 5)。 しかし, 水含量が $40 \%$ 以上では -0.5 付近まで減少する 
(1) Before Polymerization

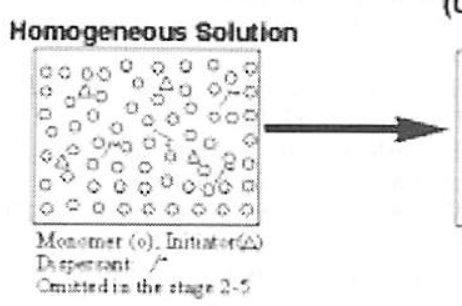

(2) Production of Insoluble (unstable) Polymers

(3) Coalescence of Unstable Microparticles
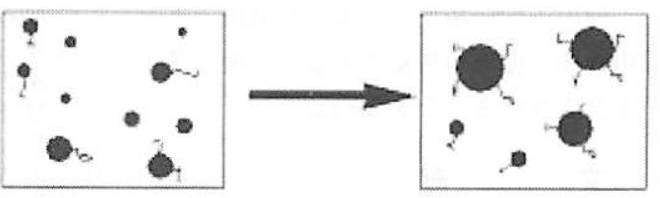

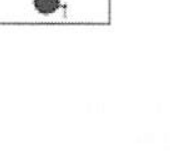

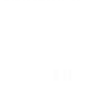

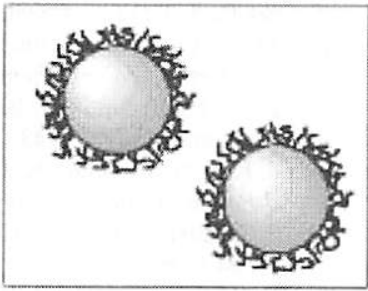

(5) Growth of Sterically

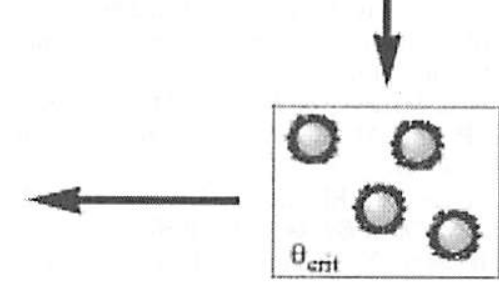

(4) Production of Sterically

Stabilized Particles at $\theta_{\text {crit }}$

図 2 分散重合のプロセスの模式図

表 5 マクロモノマーを用いた分散重合での粒子径に及ぼす指数

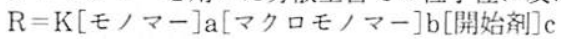

\begin{tabular}{|c|c|c|c|c|c|c|}
\hline マクロモノマー & モノマー & 連続相 & a & $\mathrm{b}$ & c & 文献 \\
\hline 理論式 (1) & & & 0.67 & -0.50 & -0.083 & \\
\hline $7, m=4, n=45$ & $\mathrm{ST}$ & メタノール/水 $(9: 1)$ & 0.63 & -0.52 & -0.068 & 72 \\
\hline $\begin{array}{l}7, m=1,4,7 \\
n=53,110\end{array}$ & BMA & メ夕ノール/水 (8:2) & 0.82 & -0.54 & -0.10 & 73 \\
\hline 7. $m=1, n=45$ & MMA & メタノール/水 $(8: 2)$ & - & -1.17 & - & 74 \\
\hline $7, m=1, n=45$ & MMA & メ夕ノール/水 $(7: 3)$ & 0.85 & -1.15 & -0.030 & 74 \\
\hline $7, m=1, n=45$ & MMA & メ夕ノール/水 $(6: 4)$ & - & -0.51 & - & 74 \\
\hline $7, m=1, n=45$ & MMA & メ夕ノール/水 $(5: 5)$ & - & -0.52 & - & 74 \\
\hline $9 b, \mathrm{~m}=11, \mathrm{n}=40$ & ST & エタノール/水 $(9: 1)$ & 1.02 & -0.60 & -0.090 & 75 \\
\hline $4, n=130$ & ST & シリコンオイル $(\mathrm{M}=2700)$ & - & -0.40 & - & 63 \\
\hline
\end{tabular}

BMA: n-butyl methacrylate

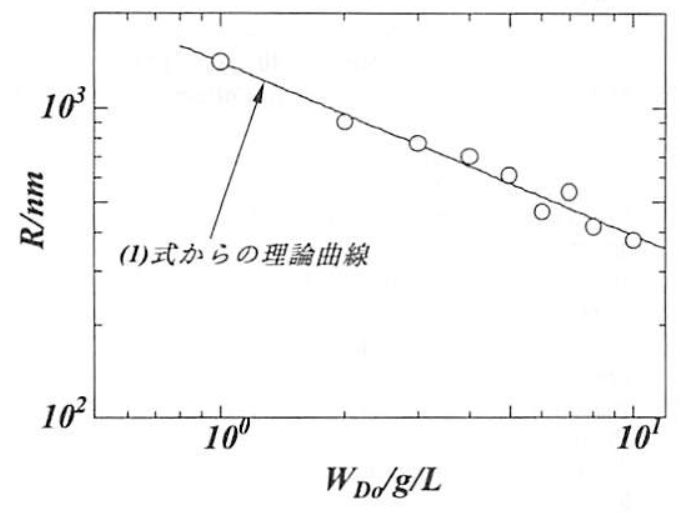

図 3 PEO マクロモノマー7を用いたスチレンの分散共重合 で得られる微粒子径のマクロモ,マー濃度依存性
ことが分かった。この高い指数の原因はまだ良く分かっ ていないが, PMMA-g-PEOのメタノールに対する親 和性（溶解性）が原因と考えられる。

以上, 連続相となじみのある極性ポリマー微粒子の粒 子径制御については, 今後の研究が必要であるが 93 95), 極性溶媒中で疎水性モノマーとマクロモノマーを用いた 分散重合で得られる粒子径は (1) 式でほぼ表されるもの と芳えられる。

\section{6.おわりに}

現在, 多種多様な機能性微粒子が分散重合によって合 成可能となっている。鍵となるのは分散剂や連続相媒体 の適切な選択にある。様々なマクロモノマーが合成可能 であるので, 様々なな機能表面をむった微粒子の合成が 
可能であろう。分散重合の粒子形成メカニズムはかなり の理解が進んできた。分散重合は重合前に均一溶液とい う定義であるので, 他の不均一系重合法よりも適用でき るモノマーや連続相媒体の種類が豊富である。今後, 多 くの新規な微粒子が合成されることを期待したい。

\section{文献}

1) K. Ito, Prog Polym Sci, 23, 581 (1998).

2) K. Ito, S. Kawaguchi, Adv Polym Sci, 142, 129 (1999).

3) S. Kawaguchi, K. Ito, Adv. Polym. Sci., 175, 299 (2005).

4) K.E.J.Barret (ed) Dispersion polymerization in organic media. Wiley, London (1975).

5) Y.Almog, S. Reich, M. Levy, Br Polym J, 14, 131 (1982).

6) C. K. Ober, K. P. Lok, M. L. Hair, J Polym Sci Polym Lett Ed, 23, 103 (1985).

7) C.M.Tseng, Y.Y.Lu, M.S.El-Aasser, J.W.Vanderhoff, J Polym Sci Polym Chem Ed, 24, 2995 (1986).

8) M. Okubo, K. Ikegami, Y. Yamamoto, Coll Polym Sci, 267, 193 (1989).

9) A. J. Paine, Macromolecules, 23, 3109 (1990).

10) K. Takahashi, S. Miyanori, H. Uyama, S. Kobayashi, J. Polym Sci Polym Chem Ed 34, 175 (1996).

11) D. Horák, J Polym Sci Part A, Polym Chem, 37, 3785 (1999).

12) K. Takahashi, S. Miyamori, H. Uyama, S. Kobayashi, Macromol Rapid Commun, 18, 471 (1997).

13) K. Takahashi, H. Uyama, S. Kobayashi, Polym J, 30, 684 (1998).

14) K. Y. Park, W. W. Jeong, K. D. Suh, J Macromol Sci, A50, 617 (2003).

15) W. Yang, J. Hu, Z. Tao, L. Li, C. Wang, S. Fu, Colloid Polym Sci, 277, 446 (1999).

16) A. Horák, P. Shapoval, J Polym Sci Part A, Polym Chem, 38, 3855 (2000).

17) B.Ray, B.M. Mandal, J Polym Sci Part A, Polym Chem, 37, 493 (1999).

18) K. Lee, S. Lee, B. Song, D. Lee, Polymer (Korea), 24(5), 629 (2000).

19) S. Margel, E. Nov, I. Fisher, J Polym Sci Part A, Polym Chem, 29, 347 (1991).

20) T. Bahar, A. Tuncel, Polym Eng Sci, 39, 1849 (1999).

21) A. Horák, M. Kryštůfek, J. Spěvaček, J Polym Sci Part A, Polym Chem, 38, 653 (2000).

22) W. Yang, H.Zhou, Z.Tao, J.Hu, C. Wang, S. Fu, J Mat Sci-Pure Appl Chem, A37, 659 (2000).

23) J. V. Dawkins, D. J. Neep, P. L. Shaw, Polymer, 35, 5366 (1994).

24) S.Watanabe, K.Ueno, K.Kudoh, M.Murata, Y.Masuda, Macromol Rapid Commun, 21, 1323 (2000).

25) S. Omi, M. Saito, S. Hashimoto, M. Nagai, G-H. Ma, J Appl Polym Sci, 68, 897 (1998).

26) D. Horák, J Polym Sci Part A, Polym Chem, 39, 3707 (2001).

27) D. Horák, J. Boháček, M. Šubrt, J Polym Sci Part A, Polym Chem, 38, 1161 (2000).

28) D. Horák, N. Semenyuk, F. Lednicky, J Polym Sci Part A, Polym Chem, 41, 1848 (2000).

29) E. Bourgeat-Lami, J. Lang, J Coll Interface Sci, 197, 293 (1998).

30) K.Li, H.D.H.Stöver, J Polym Sci Part A, Polym Chem, 31, 2473 (1993).

K. Li, H.D.H.Stöver, J Polym Sci Part A, Polym Chem, 31, 3257 (1993).
31) J. S. Downey, R. S. Frank, W-H. Li, H. D. H. Stover, Macromolecules, 32, 2838 (1999).

W-H. Li, H. D. H. Stöver, Macromolecules, 33, 4354 (2000).

32) W-H. Li, L-K. Li, H. D. H. Stöver, J Polym Sci Part A, Polym Chem, 37, 2295 (1999).

33) M. Hölderle, G. Bar, R. Mülhaupt, J Polym Sci Part A, Polym Chem, 35, 2539 (1997).

34) J-W, Kim, K-D, Suh, Colloid Polym Sci, 276, 878 (1998).

35) J-X. Huang, X-Y. Yuan, X-L. Yu, H-T. Zhang, Polym Int, 52, 819 (2003).

36) M. Schneider, R. Mülhaupt, Polym. Bull, 32, 545 (1994).

37) M. A. Awan, V. L. Dimonie, M. S. El-Aasser, J Polym Sci Part A Polym Chem, 34, 2633 (1996).

38) M. A. Awan, V. L. Dimonie, M. S. El-Aasser, J Polym Sci Part A, Polym Chem, 34, 2651 (1996).

39) I. Tausendfreund, F. Bandermann, H. W. Siesler, M. Kleimann, Polymer, 43, 7085 (2002).

40) J. Kim, S. Y. Jeong, K. U. Kim, Y. H. Ahn, R. P. Quirk, J Polym Sci Part A, Polym Chem, 34, 3277 (1996).

41) J.G.Murray, F.C.Schwab, Ind Eng Chem Pod Rev Dev, 21, 93 (1982).

42) G. B. Stampa, J Appl. Polym Sci, 14, 1227 (1970).

43) S. Keki, G. Deak, L. Daroczi, A. Kuki, M. Zsuga, Macromol Symp, 157, 217 (1999).

44) F. C. Schwab, J. G. Murray, In: Advances in Polymer Synthesis. Plenum, NY (1985).

45) A. D. Jenkins, D. Maxfield, C. G. dos Santos, D. R. M. Walton, J. Stejskal, P. Kratochvil, Makromol Chem Rapid Commun, 13, 61 (1992).

46) O. Okay, W. Funke, Macromolecules, 23, 2623 (1990).

47) M.Holderle, M. Baumert, R. Mülhaupt, Macromolecules, 30, 3420 (1997).

48) L. I. Gabaston, R. A. Jackson, S. P. Armes, Macromolecules, 31, 2888 (1998).

49) S. Sosnowski, M. Gadzinowski, S. Slomokowski, S. Penczek, J Bioact Compat Polym. 9, 345 (1994).

50) S. Sosnowski, M. Gadzinowski, S. Slomokowski, Macromolecules, 29, 4556 (1996).

51) H.Eisazadeh, K.J.Gilmore, G.C. Wallace, A.J.Hodgson, G. Spinks, G. C. Wallace, Coll Surf A, 103, 281 (1995).

52) P. Banerjee, B.M. Mandal, Synth Met, 74, 257 (1995).

53) S. P. Armes, M. Aldissi, M. Hawley, J. G. Berry, S. Gottesfeld, Langmuir, 7, 1447 (1991).

54) K.Shannon, J.E.Fernandez, J Chem Soc Chem Commun, 643 (1994).

55) D. Chattopadhyay, B. M. Mandal, Langmuir, 12, 1585 (1996).

56) J. Stejskal, M. Špírková, A. Riede, M. Helmstedt, P. Mokreva, J. Prokeš, Polymer, 40, 2847 (1999).

57) M. Okubo, T. Masuda, T. Mukai, Colloid Polym Sci, 276, 96 (1998).

58) T.K.Mandal, B. M. Mandal, J Polym Sci Part A, Polym Chem, 37, 3723 (1999).

59) M.L.Digar, S.N.Bhattacharyya, B.M.Mandal, Polymer, 35, 377 (1994).

60) H. Uyama, H. Kurioka, S. Kobayashi, Chem Lett, 795 (1995).

61) S. Kobayashi, H. Uyama, M. Ohmae, Bull Chem Soc Jpn, 74, 613 (2001).

62) S.Kawaguchi, T.Okada, K. Tano, K.Ito, Des Monomers Polym, 3, 263 (2000).

63) T. Uchida, S. Kawaguchi, K. Ito, Des Monomers Polym, 5, 285 (2002).

64) S. Kobayashi, H. Uyama, J. H. Choi, Y. Matsumoto, Proc Jpn Acad Ser B, 67, 140 (1991). 
65) S. Kobayashi, H. Uyama, S. W. Lee, Y. Matsumoto, $J$ Polym Sci Part A Polym Chem, 31, 3133 (1993). Y. Shimano, K. Sato, S. Kobayashi, J Polym Sci Part A Polym Chem, 33, 2715 (1995).

66) H.Uyama, H.Kato, S.Kobayashi, Chem Lett, 261 (1993).

67) S. Kobayashi, H. Uyama, Y. Narita, Makromol Chem Rapid, 13, 337 (1992). S. Koyabashi, H. Uyama, Kobushi Ronbunshu, 50, 209 (1993).

68) H.Furuhashi, S.Kawaguchi, S.Itsuno, K.Ito, Coll Polym Sci, 275, 227 (1997).

69) R. Shen, C. Akiyama, T. Senyo, K. Ito, Compt Rend Chimie, 6, 1329 (2003).

R. Shen, T. Senyo, C. Akiyama, T. Atago, K. Ito, Polymer, 44, 3221 (2003).

70) C. Prestige, T. F. Tadros, J Coll Interf Sci, 124, 660 (1988).

71) I. Capek, M. Riza, M. Akashi, Makromol Chem, 193, 2843 (1992). M. Riza, I. Capek, A. Kishida, M. Akashi, Angew Makromol Chem, 206, 69 (1993). I. Capek, M. Riza, M. Akashi, J Polym Sci Part A, Polym Chem, 35 , 3131 (1997). I. Capek, S. H. Nguyen, D. Berek, Polymer, 41, $7011(2000)$.

72) M. B. Nugroho, S. Kawaguchi, K. Ito, Macromolecular Reports, A32, 593 (1995).

73) S. Kawaguchi, M. A. Winnik, K. Ito, Macromolecules, 28, 1159 (1995).

74) K. Ito, Kobunshi Kako, 30, 510 (1994), T. Hattori, M. B. Nugroho, S. Kawaguchi, K. Ito, Polym. Prepr. Jpn, 45, 157 (1996).

75) J. Liu, L. M. Gan, C. H. Chew, C. H. Quek, L. H. Gan, J Polym Sci Part A Polym Chem, 35, 3575 (1997). J. Liu, C. H. Chew, S. Y. Wong, L. M. Gan, J. Lin, K. L. Tan, Polymer, 39, 283 (1998).

76) H. Imai, S. Kawaguchi, K. Ito, Polym J, 35, 528 (2003).

77) M.Akashi, T.Yanagi, E.Yashima, N.Miyauchi, J Polym Sci Part A Polym Chem, 27, 3521 (1989). T. Serizawa, S.Takehara, M.Akashi, Macromolecules, 33, 1759 (2000). M-Q. Chen, T. Serizawa, A. Kishida, M. Akashi, $J$ Polym Sci Part A, Polym Chem, 37, 2155 (1999).

78) P. Lacroix-Desmages, A. Guyot, Macromolecules, 29, 4508 (1996).

P. Lacroix-Desmages, A. Guyot, Coll Polym Sci, 274 , 1129 (1996).
79) J. S. Shay, R. J. English, R. J. Spontak, C. M. Balik, S. A. Khan, Macromolecules, 33, 6664 (2000).

80) M.Akashi, T.Yanagi, E.Yahsima, N.Miyauchi, $J$ Polym Sci Part A Polym Chem, 27, 3521 (1989).

81) I. Iwasaki, E. Yashima, M. Akashi, N. Miyauchi, K. Marumo, Polym Prepr Jpn, 40, 2597 (1991).

82) K.Ishizu, N.Tahara, Polymer, 37, 1729 (1996). K.Ishizu, M. Yamashita, A. Ichimura, Macromol Rapid Commun, 18, 639 (1997).

83) M. Riza, S. Tokura, A. Kishida, M. Akashi, Polym Prepr Jpn, 42, 4617 (1993).

84) M. Q. Chen, A. Kishida, M. Akashi, J Polym Sci Part A Polym Chem, 34, 2213 (1996).

85) M.Riza, S.Tokura, M. Iwasaki, E. Yashima, A. Kishida, M. Akashi, J Polym Sci Part A Polym Chem, 33, 1219 (1995).

86) K. Ishizu, M. Yamashita, A. Ichimura, Polymer, 38, 5471 (1997).

87) K.A.Shaffer, T.A.Jones, D.A.Canelas, J.M. Desimone, S.P. Wilkinson, Macromolecules, 29, 2704 (1996).

88) K. Ishizu, N. Tahara, Polymer, 37, 2853 (1996).

89) S. F. Lascelles, F. Malet, R. Mayada, N. C. Billingham, S. P. Armes, Macromolecules, 32, 2462 (1999).

90) T. Senyo, Y. Atago, H. Kiang, R. Shen, K. Ito, Polym J, 35, 513 (2003).

91) U. Yilidiz, B. Hazer, I. Capek, Angew Makromol Chem, 231, 135 (1995). U. Yilidiz, B. Hazer, Polymer, 41, 539 (2000).

92) E. Bourgeat-Lami, A. Guyot, Coll Polym Sci, 275, 716 (1997).

E. T. W. M. Schipper, O. Sindt, T. Hamaide, P. LacroixDesmazes, B.Müller, A.Huyot, M.J.W.A.van den Enden, F. Vidal, J.J.G.S. van Es, A.L.German, A.M.Montaya Goni, D.C.Sherrington, H.A.S.Schoonbrood, J.M.Asua, M. Sjöberg, Coll Polym Sci, 276, 402 (1998).

93) M. Yasuda, H. Yokoyama, H. Seki, H. Ogino, K. Ishimi, H. Ishikawa, Macromol Theory Simul, 10, 54 (2001).

94) M. Yasuda, H. Seki, H. Yokoyama, H. Ogino, K. Ishimi, H. Ishikawa, Macromolecules, 34, 3261 (2001).

95) P. Lacroix-Desmazes, J. Guillot, J Polym Sci Part B Polym Phys, 36, 325 (1998). 